\title{
Father-son Education in the Ancient Chinese Classics Guoyu and Zuozhuan
}

\author{
Ho-kin Tong ${ }^{1}$ \\ ${ }^{1}$ Department of Literature and Cultural Studies, Hong Kong Institute of Eduation, Hong Kong SAR, China \\ Correspondence: Ho-kin Tong, Department of Literature and Cultural Studies, Hong Kong Institute of Education, \\ 10 Lo Ping Road, Tai Po, Hong Kong SAR, China. Tel: 852-2948-7970. E-mail: hktong@ied.edu.hk
}

Received: April 20, 2020

Accepted: June 29, $2020 \quad$ Online Published: September 30, 2020

doi:10.5539/ach.v12n1p12

URL: https://doi.org/10.5539/ach.v12n2p12

\begin{abstract}
The hexagram “jiaren gua” 家人卦 (The Family) of Yijing 易经 (Book of Changes), a divination manual in the Western Zhou period (1046-771 BC) advocates a strict father image in family management. Is the Pre-Qin father really a strict figure? To answer this question, taking the two major Pre-Qin historical texts Guoyu 国语 and 左 传Zuozhuan as targets, three sub-questions will be addressed: (1) What kind of family education records are collected in these texts? (2) How is father-son education represented in these texts? (3) Why is father-son education represented in such a way in these texts? A comprehensive textual research on a father's role represented in these texts was conducted to collect relevant data to answer the three sub-questions. The data collected was then interpreted by a hermeneutics method, with educational and sociological perspectives to propose an answer to the main research question. The strict but caring fathers represented in these two learning texts are role models for learners and readers in that period. This role model creates a heavy burden on male leaders of upper class families because no matter fathers or sons, they have to have a high moral standard to safeguard their families. Being an upper class father in the Chunqiu period 春秋 (c.770-c.476 BC) is a difficult task as he has to strike a balance between strictness and love to teach his sons. This is also true for today's fathers.
\end{abstract}

Keywords: Guoyu, Zuozhuan, Father, Family Education, Ancient Chinese Culture

\section{Introduction}

Lee (2000) pointed out that studies on personality formation in educational theory and history in relation to traditional Chinese society are rare. His observation is still valid for research on ancient Chinese family education. From a Chinese perspective, family education can be taken as a process of mutual education among family members (Ma, 1997; Fan, 2006; Chen, 2008). In this paper, family education refers to the mutual education among members of a nuclear family. Xing (2003) recognized that family education is one of the research foci in family study. However, most of the works in the field have focused mainly on textual family instructions that normally refer to family seniors' commandments to their juniors (Xie, 1997; Li, 1998; Zhai, 2002; Xu \& Chen, 2003; Wang, 2006; Chen, 2008; Zhu, 2008; Zhang, 2009; Ding, 2010) rather than on the process of family education. As suggested by Chen (2008), three research directions are still needed for further development of the field: (1) focusing more on family education of various traditional social classes; (2) extending the research from post Han periods back to the Pre-Han period; (3) conducting more in-depth studies from the sociological perspective rather than general analysis of family education. Although Fan (2006) investigated the categories, aims and pedagogies of the Han dynasty (206 BC-220) family education from a sociological perspective, Chen (2008) studied the aims, pedagogies and impacts of Han intellectuals' family education while Tong $(2016,2017)$ explored the family education between King Wu (Ji Fa, ?-1043 BC; r.1046-1043 BC) and Duke Dan of Zhou 周公旦 (Ji Dan, ?-1032 BC) in the Shangshu 尚书 (Book of Documents) and Yi Zhoushu 逸周书 (Remnants of Zhou Documents) and records of family education in the Pre-Qin Confucian classics, more research into family education of upper and middle classes in the Pre-Qin period (before 221 BC) is needed to understand how family education was perceived and its impact among middle and upper classes. The paper aims to study the perceived role of fathers recorded in the historical proses Guoyu and Zuozhuan and possible impact of this perception on the common understanding of ancient Chinese fatherhood. 


\section{Research Question and Methodology}

Regarding parents' love, Fromm (1957) differentiated motherly love as unconditional but fatherly love as conditional. According to Fromm, a mother represents nature, soil, the ocean, and the home we come from while a father represents the world of thought, man-made things, law and order, discipline, travel and adventure, and is the one who teaches the child, who shows him the road into the world. In the chapter "Biaoji" 表记 (Record of Example) of Liji 礼记 (Book of Rites), it cites Kongzi's 孔子 (Confucius, 551-479 BC) words that a mother loves her children no matter whether they are virtuous and capable or not while fathers only love their virtuous and capable children (Guli bianyiguan, 2001).

In the hexagram "jiaren gua" (The Family) of Yijing (Book of Changes), a divination manual in the Western Zhou period 西周 (1046-771 BC) which became a Confucian classic in the Han dynasty 汉 (206 BC-220), it states:

If the Family is run with ruthless severity, one may regret the degree of it, yet there will be good fortune. But if wife and child overindulge in frivolous laughter, in the end it will result in baseness" (Lynn, 1994, $365)$.

A father as the manager of a family is expected to be strict and Ma (1997) argued that the tradition of the strict family management culture in China originated from this hexagram. The ideograph of $f u$ (contemporary written as 父) is represented as a family leader holding a stick to teach his children in the Shuowen jiezi 说文解字 (Explaining Graphs and Analyzing Characters), a $2^{\text {nd }}$ century Chinese dictionary compiled by Xu Shen 许慎 (?c.120) (Duan, 1988, 115). This ideograph $f u$ also carries the meaning of father because in ancient time just like the view recorded in the hexagram "jiaren gua" that father is a strict manager of family. In the Western world, Grazizni \& Lanselle (2012) contributed a collection of articles on Chinese fathers in The Father in Question which queried the supreme status of Chinese fathers and argued that starting from the Zhanguo period 战国 (Warring States period, c.475-221 BC), the patriarchal model was supplanted by the parental one. However, the collection has not discussed the fatherhood of the Pre-Qin period in detail. These controversial views of ancient Chinese fatherhood mark the importance of the research question of the paper: Is the Pre-Qin father really a strict figure?

Although currently there is no extant written records on the common people's family education of the Pre-Qin period, by referring to the chapters "Lishu" 历书 (Treatise of Calendar) and “Zhou benji" 周本纪 (Annals of Zhou) in Sima Qian's 司马迁 (?-86 BC) Shiji 史记 (Records of the Grand Historian) on inherited family knowledge, Ma (1997) proposed that one of the major function of ancient Chinese family education was the transmission of specific family knowledge and a typical example was the transmission of family knowledge of astronomy and calendars related to farming. Regarding handicrafts, in annotating the chapter "Dongguan qiaogongji” 冬官考工记 (Office of Winter and Records of Handcraft) of the Zhouli 周礼 (Rites of Zhou), Zheng Xuan 郑玄 (127-200) argued that as all craftsmen were slaves of states, the only way they learned their crafts was from their fathers (Sun 1848-1908, 1987). However, there are some written records on royal family education of the Western Zhou dynasty (1047-772 BC). In the books Shangshu and Yi Zhoushu the authors presented their views on how royal leaders of the Jis 姬氏 should behave in order to safeguard their sovereignty (Tong, 2015, 2016). As stated by Sima Qian in the “Taishigong zixu” 太史公自序 (Preface of Grand Historian) of the Shiji, assassinations of state lords and ruins of states were common, and many nobles and state officials lost their lives, families, clans and states because of misconduct, laziness in state affairs, and violation of rites (Han, 2004). In the Chunqiu 春秋 (Spring and Autumn Period, c.770-c.476 BC) and Zhanguo periods, the royal family Jis lost its authority and control over state lords. In order to avoid disasters and retain their ranks and status, many nobles and state officials paid special attention to family instructions (Xu \& Chen, 2003) and hence noble and middle-class family education replaced the royal family education as the mainstream in written texts. The two largest historical narratives Guoyu (Discourses of the States) and Zuozhuan (Zuo Tradition) are textual collections of events of the Chunqiu period and as suggested by Zhang (2013b), these textual records are valuable references for studying family education of nobles in the Pre-Qin period.

These two texts can also help us understand how writers and editors perceive the role of fathers of the nobility or intellectual class should be. This topic is important as nobles or intellectuals were rulers of the common people in ancient China. This perception can help us clarify if a father in the Chunqiu period was a strict figure. To answer this question, taking the two major Pre-Qin historical texts Guoyu and Zuozhuan as targets, three sub-questions will be addressed: (1) What kind of family education records are collected in these texts? (2) How is father-son education represented in these texts? (3) Why is father-son education represented in such a way in these texts? A comprehensive textual research on a father's role represented in the three texts was conducted to collect relevant data to answer the three sub-questions. The data collected was then interpreted by a hermeneutics method to explain what the ancient texts mean (Pan, 1999) and its process of understanding, explanation and application can 
generate creative meaning (Hong, 2001). Educational and sociological perspectives were adopted to study the unique role of a noble father in family education represented in these texts.

\section{The Family Education Records Collected in the Guoyu and Zuozhuan}

In ancient China, concepts of history, literature and philosophy had not been distinguished as clearly as today. Texts on past events, poems and thoughts were always perceived as historical records, literary writings and philosophical works in the Pre-Qin period. Currently, in the Chinese tradition, many Pre-Qin texts such as the Shangshu, Chunqiu (Spring and Autumn), Guoyu, Zuozhuan and Zhanguo ce (Strategies of the Warring States) are taken as historical texts as well as literary prose. The representations of events and figures in these texts to some extent do reflect the authors' or editors' perceptions of events and figures recorded in their works in the PreQin period.

In the chaotic political context of the Chunqiu period, many state lords and nobles lost their manors, families, clans and lives because of their poor moral conduct and behaviors. In order to avoid scourges and maintain their ranks and official salaries, most nobles pay special attention to father-son education (Xu \& Chen, 2003). Zhang (2013a) argued that family instructions of upper and middle classes recorded in the Guoyu, Zuozhuan, emphasized obedience, reverence, and being self-effacing very much and viewed being cautious and hardworking as desirable attributes that could avoid scourges. The father-son education records in these texts can be used to study how state officials' family education was perceived and represented by their writers and editors in terms of a father's role and expectations placed on their next generations. These writers' perceptions and representations are valuable references for us to know more about state officials' father-son education in the Chunqiu period.

The Guoyu is a collection of speeches and events attributed to upper class people of the Chunqiu period. The earliest speech is King Mu of Zhou (?-922 BC; r. 956-918 BC) and the latest event recorded is the execution of the Jin minister Zhibo in $453 \mathrm{BC}$. The current version has a total of 240 speeches, which are divided into eight sections by state and chronologically: “Zhouyu” 周语, “Luyu” 鲁语, “Qiyu” 齐语, “Jinyu” 晋语, “Zhengyu” 郑语, “Chuyu” 楚语, “Wuyu” 吴语, and “Yueyu” 越语 (Knechtges \& Chang 2010). The research of Guoyu mainly focuses on its authorship and completion date and ties with Zuozhuan (Liang, 2005). Sima Qian attributed both the Zuozhuan and Guoyu to Zuo Qiuming 左丘明, a contemporary of Confucius in the "Taishigong zixu” of Shiji (Han, 2004). Ban Gu 班固 (32-92) also credited the Guoyu to Zuo Qiu-ming (556 BC-451 BC) in the chapter "Sima Qian zhuan" 司马迁传 (Ban, 1962). Based on the different grammatical structure of the Guoyu and Zuozhuan, Karlgren (1889-1978) argued that these two books seem not to be authored by one person (Karlgren, 1976). Sima Guang 司马光 (1019-1086) followed his father Sima Chi's 司马池 (980-1041) view arguing that in order to elaborate the Chunqiu, Zuo Qiuming had collected many historical materials and some of the materials were selected to form the Guoyu and Zuozhuan respectively (Sima, 1987). This argument supports the view that Guoyu is probably a collection of the eight state records by Zuo Qiuming which are written by various state historians and can explain why the records vary in content details and writing style (Zhou, 2010). Based on the research outcomes of Tong Shu-ye (1935), Xu Zhongshu (1962) and Xiong Xianguang (1994) on the Guoyu's content, writings and coherency, Zhou (2010) argued that completion of the Zuozhuan should be later than the Guoyu at the beginning of the Zhanguo period. Regarding the teaching function of Guoyu, the ancient genre $y u$ 语 (speech) is a collection of ancient people's common knowledge, behavioral norms and source of speeches which mainly serves as learning materials for princes and nobles (Yu, 2007). The $y u$ is listed as one of the nine genres or knowledge in Chapter 17 of Section A of "Chuyu" 楚语: “Teaching the prince $y u$ so as to let him demonstrate his virtue and know about previous lords' persistence in applying virtue to manage the people" (Xu, 2002, 486-86). The $y u$ as a popular genre in the Pre-Qin period featuring speeches, events and interpretations can be taken as a kind of immature argumentation and the Guoyu is a typical example (Qiu, 2009). Among the 14 pieces of identified family education records, seven pieces are related to father-son education, three pieces to mother-son education, two pieces to husband-wife education and two pieces to wife-husband education in the Guoyu as listed in Table 1.

From the records of Table 1, although the father is the key figure of family education, mother and wife are also significant figures for delivering teaching to the son and husband in the Guoyu.

In China, traditionally, the Zuozhuan was a major text through which educated Chinese learned about their ancient world. The other two surviving Chunqiu commentaries, the Gongyang 公羊and Guliang 谷梁commentaries, mainly explain the wording of the Chunqiu but the Zuozhuan contains rich and lively accounts of Chunqiu events and culture. The current Zuozhuan is regarded as a commentary on the ancient Chinese chronicle Chunqiu attributed to be a work of Confucius (Kong Qiu 551-479 BC) comprising 30 chapters and covering a period from $722 \mathrm{BC}$ to $479 \mathrm{BC}$ focusing mainly on political, diplomatic, and military affairs. Its annalistic fragmentation of 
the narratives and masked voice of the writer make it a difficult text to understand but its signs and prescriptions of ritual propriety also make it readable (Durrant, Li \& Schaberg, 2016). Xu (1962) believed that the Chunqiu was Lu Chunqiu which was not written by Confucius but a transmitted national historical text of Lu state. Xu (1962) argued that after the fall of the Lu state library and the collapse of the rite and music system, many Confucius' disciples, state historians and musicians lost their jobs and had to leave $\mathrm{Lu}$ 鲁 and the Lu Chunqiu 鲁春秋, compiled by historians of $\mathrm{Lu}$, was then taken as a text book by Confucius' disciples for teaching and became the current version of Chunqiu by referring to the record in the chapter "Li shu" 礼书(Treatise on Rite) of Shiji.

Table 1. Records of family education in the Guoyu

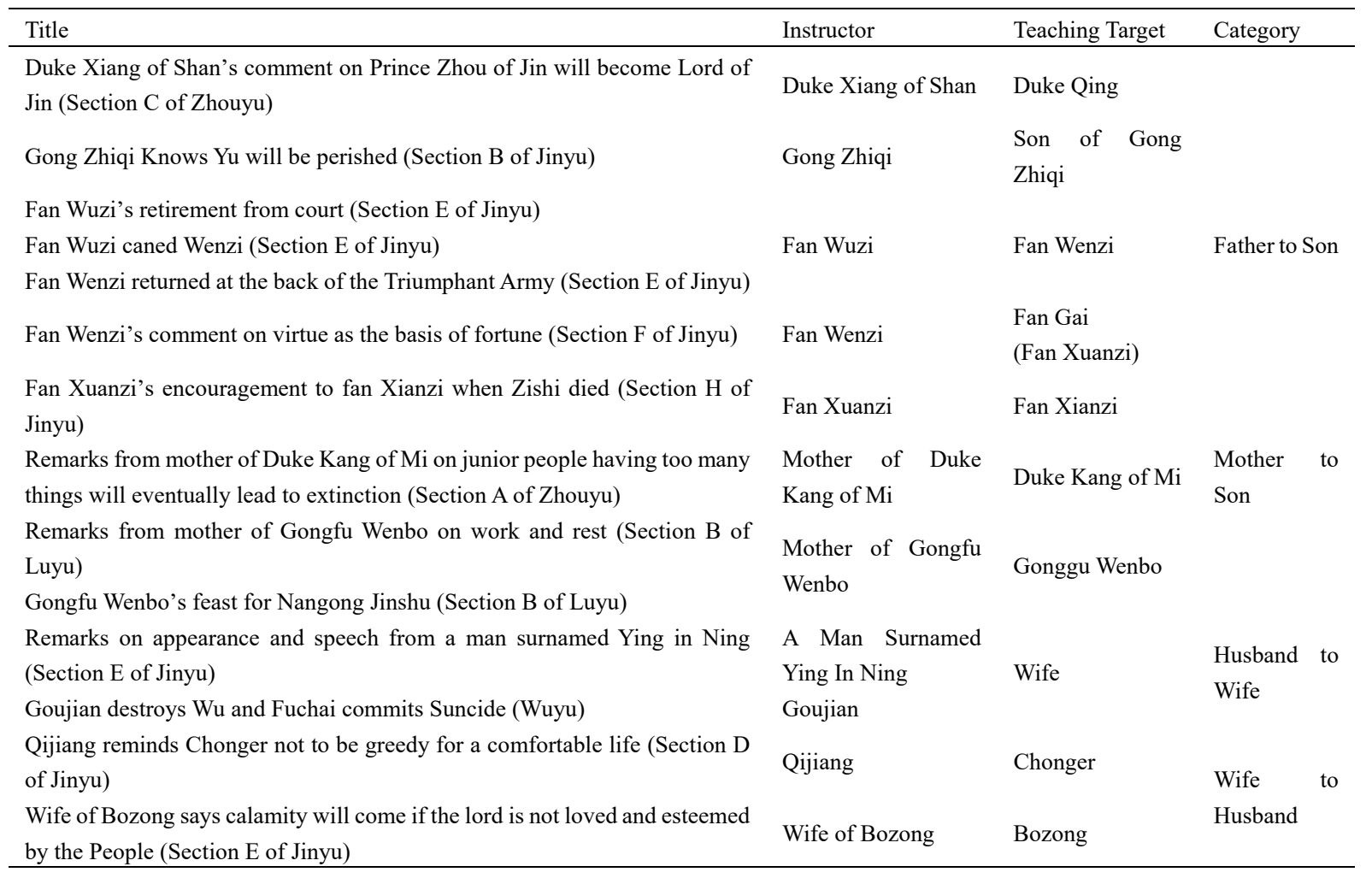

Regarding the author of Zuozhuan, there are four major views: (1) Zuo Qiuming, (2) Master Xia 子夏 (Bu Shang, 507 BC-?), (3) Wu Qi 吴起 (440-381 BC), and (4) A Lu gentleman with the surname "Zuo" 左. Liang (2005) agreed with Lu Dagui 吕大圭 (1227-1275) and Yao Nai 姚鼎 (1731-1875) that the completion of Zuozhuan was a process with contributions from different people including Zuo Qiuming and his disciples and currently scholars hold the consensus that it was largely completed by the end of the fourth century BC (Shen \& Liu, 1992; Wu, 1992; Niu, 1994; Liu, 2008; Durrant, Li \& Schaberg, 2016) and then enriched to be an annalistically arranged text (Wu, 1992; Liang, 2005; Durrant, Li \& Schaberg, 2016). There are seven identified family education records in the Zuozhuan which are listed in Table 2.

Among them only "Ziguo's teaching to his son Zichan not to criticize political affairs (8th Year of Lord Xiang, 565 BC)" is a record of father-son education and the "Ning Ying's teaching to his wife on hardness and softness (5th Year of Lord Wen, 622 BC)" is a record of husband-wife education. The other five are a mother's teaching to her children and husband. This phenomenon seems to suggest that the role of mother has become more important in family education in the Zuozhuan.

The educational functions and cultural roles of a father reflected in the identified records can provide a better understanding of fatherhood in the Chunqiu period and supplement Levi's (2012) argument on the gradual deficiency of the father in the construction of political authority in the late Zhanguo period. 
Table 2. Family Education Record in the Zuozhuan

\begin{tabular}{|c|c|c|c|}
\hline Title & Instructor & $\begin{array}{l}\text { Teaching } \\
\text { Target }\end{array}$ & Category \\
\hline $\begin{array}{l}\text { Ziguo's teaching to his son Zichan not to criticize political affairs (8th Year of } \\
\text { Lord Xiang, } 565 \mathrm{BC} \text { ) }\end{array}$ & $\begin{array}{l}\text { Ziguo } \\
\text { Zichan }\end{array}$ & $\begin{array}{l}\text { Zichan } \\
\text { Ziguo }\end{array}$ & Father to Son \\
\hline $\begin{array}{l}\text { Ning Ying's teaching to his wife on hardness and softness (5th Year of Lord } \\
\text { Wen, } 622 \mathrm{BC} \text { ) }\end{array}$ & Ning Ying & $\begin{array}{l}\text { Ning Ying's } \\
\text { Wife }\end{array}$ & Husband to Wife \\
\hline Mother of Jie Zhitui's teaching on remuneration (24th Year of Lord Xi, 636 BC) & $\begin{array}{l}\text { Jie Zhitui's } \\
\text { Mother }\end{array}$ & Jie Zhitui & \multirow{3}{*}{ Mother to Son } \\
\hline $\begin{array}{l}\text { Mother of Shuxiang's teaching on family status and continuation (21st Year of } \\
\text { Lord Xiang, } 552 \mathrm{BC} \text { ) }\end{array}$ & \multirow{2}{*}{$\begin{array}{l}\text { Mother of } \\
\text { Shuxiang }\end{array}$} & \multirow{2}{*}{ Shuxiang } & \\
\hline $\begin{array}{l}\text { Mother of Shuxiang's teaching on calamity of having a beautiful wife (28th Year } \\
\text { of Lord Zhao } 514 \mathrm{BC} \text { ) }\end{array}$ & & & \\
\hline $\begin{array}{l}\text { Mother of Yong Ji's teaching on relationship between father and husband (15th } \\
\text { Year of Lord Huan, } 697 \text { BC) }\end{array}$ & $\begin{array}{l}\text { Mother of Yong } \\
\mathrm{Ji}\end{array}$ & Yong Ji & $\begin{array}{ll}\text { Mother to } \\
\text { Daughter }\end{array}$ \\
\hline $\begin{array}{l}\text { Wife of Bo Zong's teaching on speaking the truth (15th Year of Lord Cheng, } \\
576 \mathrm{BC})\end{array}$ & Wife of Bo Zong & Bo Zong & $\begin{array}{ll}\text { Wife } & \text { to } \\
\text { Husband }\end{array}$ \\
\hline
\end{tabular}

\section{The Representation of Father-Son Education in the Records of the Guoyu and Zuozhuan?}

Father-son education is represented in these texts via "strict-father" figures who always adopt a direction instruction method to teach their sons and act as role models for their sons. These strict fathers teach their sons directly to cultivate key moral values that they think are important for state and family sustainability in a caring tone.

In Table 1, seven records on father-son education can be identified in the Guoyu. In the chapter 'Duke Xiang of Shan' of section C of “Zhouyu” 周语, it states that when Duke Xiang of Shan got a severe illness he told his son Duke Qing to treat Prince Zhou well as he would become the lord of Jin (Wu, Hu \& Li, 1994, 75-76). Duke Xiang of Shan holds this view because he thinks that Prince Zhou is a virtuous man of wen 文 who possesses 11 virtuous attributes: jing 敬 (following examples of Heaven; being modest and courteous), zhong 忠 (following one's mind; being honest), xin 信 (reflecting on oneself; being trustworthy), ren 仁 (caring for others; being loving), $y i$ 义 (benefiting others; being moderate), zhi 智 (handling affairs well; settlement of virtue), yong 勇(following righteousness; being the model of virtue), jiao 教 (distinguishing right from wrong; education of virtue), xiao 孝 (honoring the spirit; being the root of virtue), hui 惠 (being kind and harmonious; being virtuous), 让 rang (being modest to peers; applying virtue). In the record, Duke Xiang of Shan tells his son that similar to King Wen of Zhou, Prince Zhou possesses these 11 virtues which form the congregated wen virtue and reflect the order of heaven and that the Earth eventually should receive the mandate of heaven to rule the empire. Duke Xiang also teaches his son that Prince Zhou not only possesses the congregated wen virtue but also the good behavior of zheng 正 (standing up without being crooked), duan 端 (seeing without slanted eyes), ting 听 (listening without sided ears), shen 慎 (speaking without a loud voice). In addition, Duke Xiang links the alignment of dream, divination and omen with personal virtue in predicting that Prince Zhou will become lord of Jin. This prophecy eventually comes true and is reported at the end of this record. In this record, the father Duke Xiang delivers his teaching to his son Duke Qing the importance of virtue through the examples of King Wen and Prince Zhou in an expository mode and Duke Qing agrees to follow Duke Xiang's teaching. From a cultural perspective, the didactic father and submissive son seem to confirm the supreme status of the father advocated by the Yijing and a representation of virtue ruling advocated in the Shangshu by early Zhou rulers such as King Wen 文王 (Ji Chang, 1152-1056 BC), King Wu 武王 (Ji Fa, c.1087-1043 BC, r.1946-1043 BC) and Duke Dan of Zhou (Ji Dan, ?-1105 BC). Duke Xiang's intention to keep Shan safe supports the two beliefs "observe the will of Heaven" and "love the people" of the virtue-based framework of family sustainability proposed by Tong (2015). To treat Prince Zhou well is to make Shan and Duke Xiang's family safe by establishing a good relation with the future lord of the strong Jin. Under this framework, this caring father does teach his son how to safeguard the family.

It is interesting that the other six records of father-son education are all in the "Jinyu". In the chapter "Gong Zhiqi Knows Yu will Perish', Section B of "Jinyu”, minister Gong Zhiqi (c.650 BC) of Yu, after failing to advise his lord not to allow Jin trips to conquer Guo through their state, tells his son that their state will also be conquered by Jin and in order to avoid facing the calamity they have to escape to other states as the people of Jin know that their lord does not have the virtues of zhong 忠 and xin 信, the two bases of state ruling (Wu, Hu \& Li, 1994, 250- 
251). His definitions of zhong and xin are different from those in the chapter 'Duke Shan of Shan' of section B of "Zhouyu". In the chapter 'Duke Xiang of Shan', zhong and xin refer to "honesty" and "trustworthiness" respectively but in the chapter 'Gong Zhiqi Knows Yu will Perish', zhong is defined as eliminating one's ignorance to face external challenges while xin is defined as persistence in keeping an appropriate way to stand by Gong Zhiqi. Although this kind of variation on virtuous concepts is common in the Pre-Qin texts and creates a lot of debates among scholars, this may be evidence to prove that the state books are authored by different state history officers. According to Gong Zhiqi the Duke of Yu is not a ruler of zhong and xin because bringing calamities that $\mathrm{Yu}$ cannot tolerate to the state Guo is an ignorant way to face external challenges while getting money to allow Jin's trips to conquer Yu's partner Guo is not an appropriate way to establish oneself in society. Through this story, the father teaches his son that a state cannot be established without zhong and cannot be secure without xin. Yu is ruined three months after the escape of Gong Zhiqi and his family members. The aim of this affective father-son teaching delivered by a didactic method aims to advocate virtue ruling and family sustainability. Just like the case of Duke Xiang discussed above, although the father adopts a direct instruction method, his speech reveals the importance of zhong and xin for state and family sustainability in a caring tone. Gong Zhiqi is represented as a model for his son and a caring father who loves his family members.

The other five records in the "Jinyu" are all on the family Fan starting from Fan Wuzi (Shi Hui, c.660-583 BC) to Fan Xianzi (Shi Gai, ?-501 BC). In the first record the chapter 'Fan Wuzi's Retirement from Court', Section E of "Jinyu", Fan Wuzi tells his son Fan Wenzi (Shi Xie, ?-574 BC): (1) he has to retire and let Xi Ke (?-587 BC) take over him to avoid Xi Ke diverting his anger of insult from the palace women in the state Qi; (2) to follow other senior officials to observe orders of the lord and do things in respectful way (Wu, Hu \& $\mathrm{Li}, 1994,361)$. Fan Wuzi as a model father directly instructs his son to stay away from conflict, be loyal to the lord and be respectful in doing things. It is clear that Fan Wuzi's intention is to teach his son how to avoid calamities for family sustainability from a caring father's perspective who loves his son and cares about his state. This record shows the role of the father and expectations placed on the son.

In another record "Fan Wuzi Caned Wenzi" (Section E of Jinyu), Fan Wuzi is recorded as a strict father who teaches his son Fan Wuzi that he ought to be modest and not answer questions for his seniors at court (Wu, Hu \& Li, 1994, 362). Fan Wuzi condemns his son Fan Wenzi that if Fan Wenzi is not in Jin, Fan Wenzi should have already suffered from his misbehavior and then canes Fan Wenzi till Wenzi's hairpin is broken. In this father-son dialog, Fan Wuzi is represented as a strict father who teaches his son through condemnation and corporal punishment. Corporal punishment is the use of force on children to make them comply with parents, but it is not intended to cause injury (Straus and Stewart, 1999). Although Fan Wenzi is not a child, his father Fan Wuzi does use corporal punishment on Fan Wenzi so as to make him follow his instruction and keep Fan Wenzi and the Fans safe. A strict but caring father is represented in the record.

The third record on this pair of father and son is also seen in the chapter "Fan Wenzi Returned at the back of the Triumphant Army" (Section E of Jinyu). In the record, when Fan Wuzi asks Fan Wenzi why he returns home late in the triumphant return, Fan Wenzi replies that since Xi Ke is the commander and he does not want to be the focus, he therefore returns after Xi Ke. After hearing this, Fan Wuzi says "I know you can be away from calamities" (Wu, Hu \& Li, 1994, 366). In this record, it is not the father who teaches the son how to behave but the son who teaches his father how he should behave according to different roles. Xi Ke is the commander of the army and hence in the triumphant return he should be the focus, not Fan Wenzi. Fan Wenzi understands his role and the way to avoid offending Xi Ke and keep himself safe while Fan Wuzi knows that his son Fan Wenzi has grasped the way to protect himself and his family. Although we do not know exactly the dates of the three events between Fan Wuzi and Fan Wenzi, the third event should be the latest one according to the status and maturity of Fan Wenzi. The comment "I know you can be away from calamities" is a happy confirmation of the father's teaching to his son. Zhang (2013) argues that because of Fan Wuzi's teaching, Fan Wenzi can maintain his rank and family in the Jin court for more than 40 years. In the chapter "Fan Wenzi's Comment on Virtue as the Base of Fortune" (Section F of Jinyu), the father Fan Wenzi follows his father Fan Wuzi's model to apply corporal punishment to his son Fan Gai (Shi Gai) when Fan Gai says that the army of Chu will leave as they have destroyed all cooking stoves and wells before senior officials at the war of Yanling (Wu, Hu \& Li, 1994, 390). In the record, Fan Wenzi chases after Fan Gai, canes him with a dagger and says:

Survival of states is determined by will of Heaven. You little child knows what? Moreover, you have not been asked for comments but you presented your views is a kind of evil behavior. You must be killed. (Wu, Hu \& Li, 1994, 390)

After this display of corporal punishment, Miao Fenhuang (c.560 BC) comments that Fan Wenzi is good at avoiding calamities. Through performing corporal punishment before senior officials, Fan Wenzi teaches his son 
to respect Heaven's will and not to commit evil acts while Miao's comment reflects that Fan Wenzi is a responsible family leader who cares for his family's sustainability and the safety of his son. Fan Gai (Fan Xuanzi) inherits Fan Wenzi's role as leader of the Fan house.

In the chapter "Fan Xuanzi's Encouragement to Fan Xianzi When Zishi Died" (Section H of Jinyu), it states that Fan Xuanzi teaches his son Fan Xianzi (Fan Yang, ?-501 BC) after the death of his subordinate Zi Shi to consult capable people for state management of Jin ( Wu, Hu \& Li, 1994, 430). Fan Xianzi replies to his father that although Zi Shi has passed away, he himself is always respectful, does not dare to be sloppy and covet a comfortable life, studies seriously and pursues ren (benevolence) and yi (righteousness), manages state affairs harmoniously and observes the right way, plans with many people not for the obtainment of a good feeling, does not dare to be opinionated even though with good ideas and is sure to listen to seniors' words. After hearing his son's reply Fan Xuanzi says Fan Xianzi can be away from calamities. Fan Xuanzi as a responsible family leader and caring father believes that his son and the Fans can be safe because his son has good moral conduct and can accept advice from other people and seniors.

There is only one record of father-son education titled "Ziguo's teaching to his son Zichan not to criticize political affairs" (8th Year of Lord Xiang, 565 BC) in the Zuozhuan. It states:

On the gengyi (22), Ziguo and Zi'er of Zheng invaded Cai and captured the Cai supervisor of the military, Gongzi Xie. The leaders of Zheng all pleased. Only Zichuan did not go along but said, "For a small domain, there is no greater calamity than to lack civil virtue and to have instead martial achievement. When the men of Chu come to chastise us, can we not submit to them? But if we submit to them, Jin troops will certainly come. And if both Jin and Chu attack Zheng, Zheng will have no peace for at least the next four to five years." Infuriated, his father, Ziguo, said, "What can you know! The domain has its great command, for which it has its chief minister. This is a child speaking-for this you may be executed!” (Durrant, Li \& Schaberg, 2016, 943)

In the record, after knowing that Ziguo and Zi'er of Zheng invaded Cai and captured Gongzi Xie, leaders of Zheng are all pleased but Zichuan points out that the military achievement may lead to invasions from Jin and Chu and criticizes Zheng's ignorance of civil virtue. However, his father teaches him that what he says will cause him to be executed as that should be the responsibility of relevant chief ministers. This father loves his son and warns his son not to say anything that may cause calamity to his son and his family. The states belonged to their lords' families and hence this caring father educates his son from perspectives of personal safety and family sustainability instead of civil virtue and state safety. However, Zichan's comment on the consequence of invading Cai which eventually happens in the record represents a smart son's criticism of his father's and chief ministers' decisions and actions. If father-son education is a mutual education then Zichan does teach his father Ziguo that he is wrong. Ziguo as a father and Zichan as a son are both teacher and learner in this father-son education process. The aim of Ziguo's teaching to Zichan not to comment on chief ministers' decisions is to avoid being executed. Zichan's teaching to his father Ziguo represents a new role perception of the son which challenges the supreme status of the father in the Yijing.

In the above records, the fathers teach their sons to: (1) observe the will of Heaven; (2) love the people you manage; (3) cultivate personal morality and apply moral ruling; and (4) conform to role norms. It seems that the upper class father represented in the Guoyu and Zuozhuan is a strict figure. Fan Wuzi and Fan Wenzi adopt corporal punishment and condemnation to teach and care for their sons. However, from the above four major expectations on the sons, these noble fathers demonstrate great care about the personal safety of individual family members and sustainability of their families. In this sense, strict pedagogy may just be a means to achieve the father's love for family members and the whole family.

\section{The Ideology of Father-Son Education Represented in the Guoyu and Zuozhuan}

The father-son education discussed above reflects the ideology of the upper class in the Western Zhou period. This ideology is a reflection of the belief "Heaven's mandate - cultivation of morality - protect the people". According to records in the chapter "Zhaogao" 召诰 (Announcement of Duke Zhao) of Shangshu (Kong 1990), the belief of Heaven's Mandate emerged as early as in the Xia dynasty 夏 (c.2070-1600 BC) and further developed in the Shang 商 (c.1600-1046 BC) and Zhou dynasties. Early Zhou rulers claimed that their sovereignty was given by Heaven because of their high morality of ruling that would benefit the people and the people's views were always followed by Heaven in the chapters "Qinshi" 泰誓 (Speech of the Marquis of Qin) and "Kanggao" 康诰 (Announcement to the Prince of Kang) of Shangshu (Kong 1990). Qiao (1988) argued that this strategy was a synergy of religion, politics and ethics and through this strategy the early Zhou leaders justified their overthrowing of the Shang dynasty. Under this belief, male leaders of the royal Zhou families were expected to possess a high 
personal moral standard and practice ethical ruling for the benefit of the people as Heaven would only mandate someone who could benefit the people. This great expectation created a heavy burden not only on male leaders of the royal Zhou family but also on noble families. The male leaders of various states and senior officials had also to have high moral standards, benefit the people, and obey their lords and seniors to safeguard their nobilities and families. The Zhou kings integrated Heaven's will into the patriarchal system to safeguard their sovereignty. As pointed out by Zhu (2009), based on the moral concept of filial piety, the early Zhou leaders advocated moral ruling that could benefit the people and keep the mandate of Heaven.

It seems that noble fathers who delivered strict instructions to their sons represented in the Guoyu and Zuozhuan discussed above do share the belief that "Heaven's mandate - cultivation of morality - protect the people". Ma (1997) illustrated this kind of father's "strictness" in six dimensions with reference to the hexagram "jiaren gua" and commentaries on the early Chunqiu period classic Yijing (Zhang 1994): (1) supreme status of senior members in families; (2) role differentiation of family members; (3) emphasis on education to prevent mistakes and punishments; (4) integration of being strict and love; (5) integration of majesty and integrity; and (6) integration of family education and self-regulation and claimed that the "jiaren gua" started the conceptualization of the "strict" father in ancient China. However, the Chinese lexical yanfu 严父 first appeared in the chapter "Shengzhi” 圣治 (The Government of the Sages) of early Zhanguo period classic Xiaojing 孝经 (The Classic of Filial Piety) (Zhang 1996) does not carry any meaning of strictness. In the chapter "Shengzhi" of Xiaojing it states:

Master Zeng said, "May I presume to ask if there is anything in the excellence (de) of the sages that surpasses family reverence?" The Master replied, "Of all the creatures in the world, the human being is the most noble. In human conduct there is nothing more important than family reverence; in family reverence there is nothing more important than venerating one's father (yanfu); in venerating one's father there is nothing more important than placing him on a par with tian. And the Duke of Zhou was able to do this. (Rosemont \& Ames 2009, 110)

The lexical yanfu here refers to "venerating one's father" not "strict father". However, in the chapter "Nan yi" (Difficulty One) of the late Zhanguo period classic Hanfeizi (Ma 2013), it states:

Now Shikuang criticizes Duke Ping's fault, pick up the zither to hit his body. Even a strict father (yanfu) will not treat his son in such a way. (Chen 2000, 859)

It is interesting that according to this message, the yanfu in Hanfeizi 韩非子 is not really a strict father as he will not hit his son with a zither. Although Han Fei 韩非 (?-233 BC) emphasizes the importance of a strict father educating children (Ma 1997), he concludes that state punishment is far more effective than parents' love in regard to regulating children's behaviors in the chapter “Wu du” 五冨 (Five Vermin):

Thus the love of parents is not enough to make children learn what is right, but must be backed up by the strict penalties of the local officials; for people by natural grow proud on love, but they listen to authority. (Chen 2000, 1099; Watson 2003, 104)

Ma (1997) argued that Han Fei held this view because he was strongly influenced by Xunzi's 荀子 (c.310 BCc.235 BC) doctrine of evil human nature, and legalists Shang Yang's 商鞅 (c.390 BC-338 BC), Shen Buhai's 申 不害 (c.400 BC-c.337 BC) and Shen Dao's 慎到 (c.395 BC-315 BC) views on the rule of law. On one hand Han Fei knows the importance of being a strict father in family education and on the other hand he also knows that in reality it is not easy to act as a strict father. What Han Fei can do is to shift the responsibility to state laws. The six fathers, Duke Xiang of Shan, Gong Zhiqi, Fan Wuzi, Fan Wenzi, Fan Xuanzi and Ziguo discussed above are all caring fathers and among them only Fan Wuzi and Fan Wenzi have carried out corporate punishment on their sons but with a caring attitude. The hexagram "jiaren gua" of Yijing has not established a real "strict father" perception in the Guoyu and Zuozhuan with reference to the above discussion. I would say in general that the fathers represented in the Guoyu and Zuozhuan are perceived as caring fathers by the authors and editors of the two texts and corporal punishment may just be a means to achieve the good intentions of fathers just like Fan Wuzi and Fan Wenzi.

\section{Conclusion}

Among the 14 identified family education records in the Guoyu, seven are on father-son education, three are on mother-son education, two are on husband-wife education and two are on wife-husband education. In the seven identified family education records Zuozhuan, there are only one record on father-son education and another on husband-wife education; the other five are mothers' teaching to children and husbands. It seems that although the father is a key figure of family education in the Guoyu and Zuozhuan, the mother and wife are also important in delivering teaching on moral leadership and survival skills to the son and husband. All these identified father-son 
records are valuable resources for us to understand how the authors and editors perceive the role of father in family education in the Chunqiu and Zhanguo periods.

The "strict fathers" represented in these two classics teach their sons to cultivate moral values which are important for state and family sustainability. Their main instructions include: (1) observing the will of Heaven; (2) loving the people you manage; (3) cultivating personal morality and applying moral ruling; and (4) conforming to role norms. In addition to direct instruction, sometimes they also apply corporal punishment and condemnation to teach their sons. However, from the above four major expectations on their sons, these fathers demonstrate great care about the personal safety of their sons and sustainability of their families as well. In this sense, the "strict fathers" represented in the texts are caring fathers for their family members, families and states and are role models for their sons and readers of the texts. The caring father Ziguo in the Zuozhuan being taught by his son Zichan on the dangerous decision of senior court officials is an example of mutual education between father and son that challenges the supreme father proposed by the Yijing.

This role model creates a heavy burden on male leaders of upper class families as they are expected to have high moral standards, benefit their people, and obey their lords and seniors as well as cultivate their sons to develop this mindset to safeguard their nobility and families. The hexagram "jiaren gua" of Yijing has not established a real "strict father" perception in the Guoyu and Zuozhuan. Being an upper class father in the Chunqiu period is a difficult task as he is expected to have high moral standards, safeguard his family and cultivate his sons to develop similar mindset in a caring way.

\section{Conflict of interests}

The authors declare that there is no conflict of interests regarding the publication of this paper.

\section{References}

Ban, G. (1962). Han-shu (Vol. 1-12). Beijing: Zhonghua shuju.

Chen, C.F. (2008). Handai shiren jiating jiaoyu yanjiu. Fujian Normal University Master Dissertation, .

Chen, Q.Y. (2000). Hanfeizi xinjiaozhu (Vol.1-2). Shanghai: Shanghai guji chubanshe.

Ding, C. (2010). Gudai jiaxun. Changchun: Jinlin wenshi chubanshe.

Duan, Y.C. (1735-1815). (1988). Shuowen jiezi zhu. Shanghai: Shanghai guji chubanshe.

Durrant, S., Li, W.Y., \& Schaberg, D. (tr.). (2016). Zuo Tradition/Zuozhuan: Commentary on the "Spring and Autumn Annals" (Vol. 1-3). One Seattle and London: University of Washington Press.

Fan, X.R. (2006). Lianghan jiatingjiaoyu yanjiu. Heibei University MA Dissertation.

Formm, E. (1957). The Art of Loving. London: George Allen \& Unwin.

Graziani, R., \& Lanselle, R. (eds.). (2012). Instituted Father, Questioned Father: The Father in Question. Paris: Presses Universitaires de Vincennes.

Guli bianyiguan. (ed.). (2001). Liji zhushu. Taibei: Xinwenfeng chubangongsi.

Han, Z.Q. (2004). Shiji jianzheng. Nanchang: Jiagnxi renmin chubanshe.

Hong, H.D. (2001). Quanshixue: tadelishi he dandai fazhan. Beijing: Renmin chubanshe.

Karlgren, B. (1976). Zuochuan zhenwei kao ji qita. In Chen Xinxiong \& Yu Dacheng (Eds.), Zuozhuan lunwenji (pp. 1-60). Taibei: Muduo chubanshe,

Knechtges, D. R., \& Chang, T.P. (eds.). (2010). Ancient Early Medieval Chinese Literature, A Reference Guide, Part One. Leiden \& Boston: Koninklizke Brill. https://doi.org/10.1163/nij9789004191273_i-792

Kong, A.G. (?-408). (1990). Shangshu Zhengyi. Shanghai: Shanghai guji chubanshe.

Lee, T. (2000). Literacy, Family and Technical Education. Education in Traditional China: A History. Leiden: Brill. https://doi.org/10.1163/9789004389557

Levi, J. (2012). The Insufficient Father. Reflections on Early Chinese Political Rhetoric. In R. Graziani \& R. Lanselle (Eds.), The Father in Question (pp. 51-81). Paris: Presses Universitaires de Vincennes.

Li, M.X. (1998). Zhonghua chuanshi jiaxun. Beijing, Renmin ribao chubanshe.

Liang, T. (2005). 20 shiji yilai Zuozhuan Guoyu chengshu zuozhe ji xingzhi di taolun. Handan xuebao, 15(4), 7677.

Liu, L.M. (2008). Chunqiu jingzhuan yanjiu. Chengdu: Bashu shushe. 
Lynn, R. J. (1994). The Classic of Changes. New York: Columbia Press.

Ma, S.N. (2013). Xianqin zishu de bianji yu zhuoxinshidai de jingdian shengcheng. Wenshizhe, 1, 101-167.

Ma, Y. (1997). Preface. Zhongguo jiating jiaoyushi. Changsha: Hunan jiaoyu chubanshe.

Niu, H.G. (1994). Lun Zuozhuan di chengshu niandai. Shoudu shifan daxue xuebao (shehui kexue ban), (5), 1928.

Pan, D.R. (1999). Quanshixue daolun. Taibei: Wunan.

Qiao, G. (1988). Xizhou tianminglun yu zhongguo gudi zhexue di fasheng. Xizang minzuxueyuan xuebao (shehui kexueban), 33\&34, 13-20.

Qiu, Y. (2009). Yan, yu, lun shuo yu xianqin lunshuo wenti. Kunming: Yunnan chubanshe.

Rosemont, H., \& Ames, R. T. (2009). The Chinese Classic of Family Reverence: A Philosophical Translation of the Xiaojing. Honolulu: University of Hawaii Press. https://doi.org/10.21313/hawaii/9780824832841.001.0001

Shen, Y.C., \& Liu, N. (1992). Chunqiu Zuozhuan xue shigao. Nanjing: Jiangsu guji chubanshe.

Sima, G. (1019-1086). (1987). Jingyi kao. Siku quanshu (Vol. 679). Shanghai: Shanghai guji chubanshe.

Straus, M. A., \& Stewart, J. H. (1999). Corporal punishment by American parents: National data on prevalence, chronicity, severity, and duration, in relation to child, and family characteristics. Clinical Child Family Psychology Review, 2, 55-70. https://doi.org/10.1023/A:1021891529770

Sun, Y.R. (1848-1908). (1987). Zhouli Zhengyi. Beijing: Zhonghua shuju.

Tong, H.K. (2015). The Family Instructions of Ji Dan Recorded in the Book of Documents. Asian Culture and History, 7(1), 240-249. https://doi.org/10.5539/ach.v7n1p240

Tong, H.K. (2016). The Family Education between King Wu and Ji Dan in the Ancient Chinese Book: Remnants of Zhou Documents. The International Journal of Humanities \& Social Studies, 4(5), 271-278.

Tong, H.K. (2017). The Ancient Chinese Views of Family Education Recorded in Pre-Qin (before 221 BC) Confucian Classics. Journal of Arts \& Humanities, 6(5), 42-54. https://doi.org/10.18533/journal.v6i5.1166

Tong, S.Y. (1935). Guoyu yu Zuozhuan wenti houan. Zhejiang shengli tushuguan guankan, 4(1), 81-95.

Wang, C.J. (2006). Chuantong jiaxun sixiang tonglun. Changchun: Jilin chubanshe.

Watson, B. (2003). Han Feizi Basic Writing. New York: Columbia University Press.

Wu, G.Y., Le, G.W., \& Li, X.L. (1994). Guoyu yizhu. Shanghai: Shanghai guji chubanshe.

Wu, X.F. (1992). Zuozhuan Zhengyi zhushuo shuping. Zhejian xuekan, (1), 108-113.

Xie, B.Q. (1997). Zhongguo jiaxun jinghua. Shanghai, Shanghai shehui kexueyuan chubanshe.

Xing, T. (2003). Ershi shiji guonei zhongguo jiating shi yanjiu shuping. Zhongguo shi yanjiu dongtai, (4), 16-21.

Xiong, B.G. (1994). Guoyu fengge nanbei yiqu. Shixueshi yanjiu, 3, 25-32.

Xu, S.J., \& Chen, Y.B. (2003). Zhongguo jiaxunshi. Xian: Shanxi renmin chubanshe.

Xu, Y.G. (2002). Guoyu jijie. Beijing: Zhonghua shuju.

$\mathrm{Xu}$, Z.S. (1962). Zuozhuan de zuozhe ji qi chengshu niandai. Lishi jiaoxue, 11, 28-40.

Yu, Z.H. (2007). Yu, an ancient genre - using category of yan as example. Wenshizhe, 1, 5-22.

Zhai, B. (2002). Zhongguo jiaxun jingdian. Haikou, Hainan chubanshe.

Zhang, G.M. (2009). Zhonghua chuanshi jiaxun. Huihe haote: Neimenggu renmin chubanshe.

Zhang, J. (2013a). Analysis of Fan's Parental Instructions in Zuo's Commentary and Guoyu. Journal of Zhengzhou Institute of Aeronautical Industry Management (Social Science Edition), 32(2), 64-67.

Zhang, J. (2013b). Xinqin Lianghan jiaxun yanjiu. Zhengzhou University Master Dissertation.

Zhang, T. (1996). Xiaojing zuozhe yu chengshu niandai kao. Zhongguoshi yanjiu, 1, 122-128.

Zhang, X.M. (2013). Chunqiu zhanguo zhi xihan zhongqi funu diwei yanjiu. Shandong University Master Dissertation.

Zhang, Z.T. (1994). Yijing chengshu niandai xinzheng. Anhui daxue xuebao (zhexue shehuikexueban), 1, 45-49. 
Zhou, J. (2010). Guoyu yanjiu. Soochow University Master Dissertation.

Zhu, M.X. (2008). Zhongguo jiaxunshi lungao. Chengdu: Bashu shushe.

Zhu, Y.T. (2009). Zhongguo chuantong sixiangshi (4th ed.). Shanghai: Huadong sifan daxue chubanshe.

\section{Copyrights}

Copyright for this article is retained by the author(s), with first publication rights granted to the journal.

This is an open-access article distributed under the terms and conditions of the Creative Commons Attribution license (http://creativecommons.org/licenses/by/4.0/). 